\title{
A Further Study of China Biscuit Placers in Stoke-on-Trent
}

\author{
E. POSNER and M. C. S. KENNEDY \\ From the Stoke-on-Trent Mass Radiography Service and the Department of Respiratory Physiology, \\ City General Hospital, Stoke-on-Trent
}

Powdered alumina has been used in the china industry of Stoke-on-Trent for first or 'biscuit' placing for about 30 years. An investigation of 169 placers and oven oddmen, more than half of whom had been working with alumina for more than 15 years, revealed no cases of radiologically manifest pneumoconiosis which could be related to the inhalation of alumina.

The results of the indirect maximum breathing capacity measured in 166 men were perhaps less convincing than the radiological evidence due to the different age structures of the groups examined. However, there was no evidence that the inhalation of alumina used in pottery manufacture causes pulmonary dysfunction.

The bedding or placing of fine china ware into powdered flint during first or 'biscuit' firing used to be the most serious respiratory hazard in the North Staffordshire Pottery Industry and led to the substitution of alumina for flint in the 1930s. A comprehensive account of the events leading to this major contribution in the prevention of silicosis in this country was given in a Milroy lecture by Meiklejohn, published in this journal (1963).

About 15 years after all china factories in Stokeon-Trent had substituted alumina for flint as a bedding medium and eight years after the use of flint for such purposes had been officially prohibited by the Pottery (Health) Special Regulations of 1947, King, Harrison, Mohanty, and Nagelschmidt (I955) reported that certain types of alumina could produce severe fibrosis in the lungs of rats. Consequently, an immediate radiological examination of the china placers and oddmen working at the china biscuit kilns was initiated by Meiklejohn and Posner (1957). No cases of pneumoconiosis were detected in men who had been exposed to alumina only. The findings seemed to be reassuring, but at the time of the investigation only a few workers had been exposed to alumina for more than 15 years. The investigators therefore suggested that the problem 'should be kept under further vigilant observation'.

By the winter of 1964, more than half of the china biscuit placers and oddmen in the area had been exposed to alumina dust for more than 15 years. Furthermore, one large factory had lately introduced

Received for publication June 22, 1966. a new method-profile placing-which dispensed with the use of powdered bedding media altogether. This method is likely to be adopted by most other firms in coming years. Thus the time seemed ripe for a review and possibly final re-assessment of the situation. In addition, the establishment of a respiratory physiology department in Stoke-onTrent enabled us to add objective function tests to the radiological investigations and an enquiry into respiratory symptoms.

\section{Present Investigation}

The survey was carried out during the autumn and winter of $1964 / 65$. Since the previous investigations in 1956, the china industry in Stoke-on-Trent had been the subject of extensive reorganization and amalgamation of factories with the result that only I9 factories had to be visited compared with 25 at the preceding survey. Unlike in 1956, no attempt was made to restrict the investigation to men who had been exposed to alumina only. Experience had shown that the films of workers with exposure to other dusts, such as coal or flint, were useful in avoiding bias in the interpretation of chest radiographs which were read without knowledge of employment histories.

The manufacturers were asked to provide lists of all male china biscuit placers and oddmen in their employment. Altogether 186 men were invited by a personal letter to complete a questionnaire on a precise occupational history since leaving school, on respiratory symptoms, smoking habits, and clinical histories. 
One hundred and sixty-nine men presented themselves for radiography and completed the questionnaire, a response of $90.8 \%$, which was higher than in $1956(84.6 \%)$. For various extraneous reasons, three men were unable to complete the respiratory function test. All three had worked with other dusts in addition to alumina, but their radiographs showed no evidence of pneumoconiosis.

One of us (E.P.) checked, completed, and, if necessary, corrected the men's questionnaires at the time of their attendance. This was followed by simple spirometry when four consistent expiratory spirograms were obtained using a 'Vitalograph'. Finally a full-sized chest film (I2 $\times 15$ or $14 \times$ I7 in.) was taken.

\section{Results}

Age Structure The age structure of the population examined is shown in Table I. As would be expected, the proportion of younger men was

TABLE I

Age Distribution of 169 China Biscuit Placers

\begin{tabular}{c|c|c|cc}
\hline \multirow{3}{*}{ Age (yrs.) } & \multicolumn{2}{|c|}{ Alumina Only } & \multicolumn{2}{c}{$\begin{array}{c}\text { Alumina and } \\
\text { Other Dusts }\end{array}$} \\
\cline { 2 - 5 } & No. & \% of Total & No. & $\%$ of Total \\
\hline$<25$ & I5 & 26 & 5 & 4.5 \\
$25-34$ & II & 19 & 5 & 4.5 \\
$35-44$ & 24 & 41 & 20 & 18 \\
$45-54$ & 5 & 9 & 40 & 36 \\
$55-64$ & 3 & 5 & 38 & 34 \\
$65+$ & - & - & 3 & 3 \\
\hline Total & 58 & 100 & I I I & 100 \\
& & & & \\
\hline
\end{tabular}

TABLE II

Time Worked with Alumina by i69 China Biscuit Placers AND ODDMEN

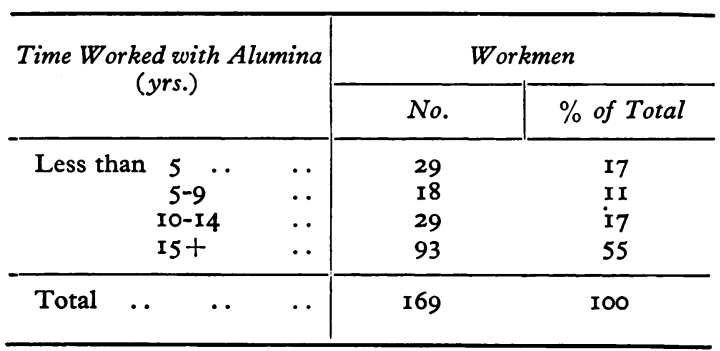

considerably higher in the group exposed to alumina only. A considerable number in this group had started to work as china placers after the substitution of flint by alumina and had, therefore, not been exposed to 'other dusts'. Of the 8I men above the age of 45 years who had been exposed to alumina and other dusts, $55 \%$ had been working with flint as china placers, the remainder were either ex-miners or potters who had been working in other departments of the ceramic industry. Table II summarizes the length of time the 169 china biscuit placers and oddmen had worked with alumina.

Radiological Investigation Each of us read all the films independently without knowledge of the occupational or clinical history of the men and classified the radiographs according to the ILO-Geneva classification (1959) with the aid of the appropriate Standard Films. We encountered considerable difficulties with regard to ' $Z$ ' shadows (increased lung markings) and ' $L$ ' shadows (numerous linear or reticular opacities). A combined reading session, however, resulted in agreement about I6I radiographs and disagreement over eight. No agreement was reached with regard to the presence or absence of pneumoconiosis in four and with regard to the stage of pneumoconiosis in another four instances. We sent these eight films to Dr. W. W. Jones, senior member of the Pneumoconiosis Panel in Birmingham, and accepted his readings for our analysis. It should be mentioned that none of these eight films was of a man who had worked with alumina only.

Pneumoconiosis Present Pneumoconiosis was suspected or diagnosed in 32 men (Table III) all of whom had been exposed to dusts other than alumina for varying periods. Twenty-four men had been using flint in addition to alumina, and in five men the length of exposure to flint was less than five years. However, as has been pointed out elsewhere, this is not an uncommon experience (Meiklejohn and Posner, 1957). The other men were either ex-miners or had worked in other departments of the pottery industry where there are recognized hazards from dust. Some had a very mixed history.

Pneumoconiosis Absent The radiographs of 137 men showed no evidence of pneumoconiosis. There were no cases of active tuberculosis or of neoplasm. Other abnormal findings were as follows: three cases of inactive tuberculosis; two cases of bronchiectasis; two cases of post-inflammatory pleural thickening; and four cases with abnormally translucent lung fields, flattened and low diaphragms, and narrow heart silhouettes, suggesting emphysema. 
TABLE III

Occupational History and Radiological Category of 32 China Biscuit Placers and Oddmen WITH PNEUMOCONIOSIS

\begin{tabular}{|c|c|c|c|c|c|c|}
\hline \multirow{2}{*}{ No. } & \multirow{2}{*}{ Age } & \multicolumn{4}{|c|}{ Exposure to Industrial Dusts (yrs.) } & \multirow{2}{*}{$\begin{array}{c}\text { Radiological } \\
\text { Category }\end{array}$} \\
\hline & & Alumina & Flint & Coal & Others & \\
\hline $\mathbf{I}$ & 64 & 19 & $2 I$ & 6 & - & $\mathrm{mr}$ \\
\hline 2 & 59 & 17 & 12 & - & 一 & mI \\
\hline 3 & 54 & 5 & - & 12 & 一 & m2 \\
\hline 4 & 47 & 14 & 一 & 15 & - & $\mathrm{m} 2$ \\
\hline 5 & 44 & 23 & 4 & - & 一 & $\mathbf{Z}$ \\
\hline 6 & 63 & 23 & 19 & - & Pottery dipper I & $\mathrm{m}_{3} / \mathrm{B}$ \\
\hline 7 & 59 & 22 & 23 & - & - & $\mathrm{m2}$ \\
\hline 8 & 62 & 19 & 9 & 9 & 一 & $\mathrm{m} 2 / \mathrm{B}$ \\
\hline 9 & 48 & 22 & 6 & 4 & 一 & p2 \\
\hline Io & 64 & 25 & 25 & 一 & 一 & $\mathrm{mI}$ \\
\hline I I & 64 & 26 & 24 & - & - & $\mathbf{m} 2$ \\
\hline 12 & 63 & 23 & 23 & - & - & mI \\
\hline 13 & 51 & 20 & 8 & 2 & 一 & mI \\
\hline 14 & 59 & I4 & 2 & 8 & 一 & pI \\
\hline 15 & 42 & 21 & 4 & 一 & 一 & $\mathbf{m 2}$ \\
\hline 16 & 53 & 25 & 8 & - & Earthenware placer 3 & pr \\
\hline 17 & 40 & 19 & 4 & 一 & 一 & pr \\
\hline 18 & 48 & 18 & 7 & - & Clay manager 4 & mI \\
\hline 19 & 45 & 20 & 9 & - & - & $\mathbf{m} 2$ \\
\hline 20 & 73 & 25 & 15 & 一 & Teapot turner ro & $\mathbf{m 2}$ \\
\hline 21 & 60 & 15 & 20 & 5 & 一 & $\mathbf{L}$ \\
\hline 22 & $6 I$ & 23 & 12 & - & Saggarmaker 5 & mI \\
\hline 23 & 52 & 18 & 一 & 14 & - & $\mathrm{mI}$ \\
\hline 24 & 42 & 14 & 一 & 15 & 一 & $\mathbf{L}$ \\
\hline 25 & 59 & 15 & 一 & 10 & 一 & $\mathbf{Z}$ \\
\hline 26 & 53 & I3 & - & - & Blunger charger I5 & $\mathbf{L}$ \\
\hline 27 & 60 & 14 & - & - & Earthenware turner 30 & m2 \\
\hline 28 & 51 & 16 & 5 & - & Earthenware dipper 8 & pI \\
\hline 29 & 63 & 24 & 20 & - & 一 & $\mathrm{m} 2$ \\
\hline 30 & 63 & 3 & 一 & $3 \mathbf{I}$ & - & $\mathrm{mr}$ \\
\hline $3 \mathbf{r}$ & 4I & 15 & 6 & - & - & $\mathrm{mr}$ \\
\hline 32 & 50 & 25 & 9 & 一 & - & pI \\
\hline
\end{tabular}

Cases $\mathrm{I}$ to 4 are also shown under the corresponding numbers in Table IX.

Respiratory Symptoms The 169 men in this series are not a representative sample of the male population of Stoke-on-Trent nor of the approximately 20,000 men at present employed in the local pottery industry. Comparisons with these populations or with the results of investigations elsewhere were not envisaged at the start of our survey. We attempted, however, a comparison between the three main groups in our series, i.e., men who had worked only with alumina, men who had worked with other dusts but whose radiographs did not show pneumoconiosis, and men who had pneumoconiosis. For this purpose the full range of questions used by Fletcher, Elmes, Fairbairn, and Wood (1959), by Higgins, Cochrane, Gilson, and Wood (1959), and by other investigators seemed to be unnecessary and too time-consuming. We therefore restricted our enquiries to simple questions which would allow us to define three groups:

I. No symptoms.

2. Simple syndrome of chronic bronchitis or phlegm production, similar to that used by Ferris and Anderson (1962).

3. Complex syndrome (College of General Practitioners, 196I) involving dyspnoea and repeated chest illnesses in addition to persistent phlegm production.

The simple syndrome was diagnosed when positive answers were given to one or both of these questions: 
TABLE IV

Respiratory Symptoms of 169 China Placers and Oddmen, according to Age and Exposure to Dusts

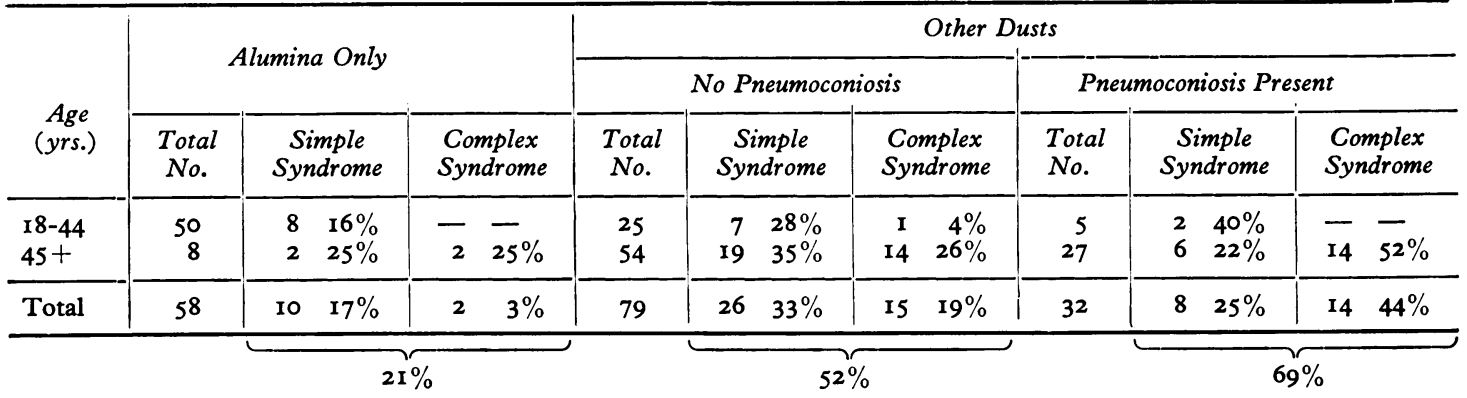

I. Do you bring up any phlegm at all when getting up in winter?

2. Do you usually bring phlegm up from your chest?

In addition, we asked the men how long they had been noticing these symptoms. With the exception of three men below the age of 34 years, all others had been suffering from these symptoms for two years or more.

The complex syndrome was based on positive answers to the questions:

I. Do you bring up phlegm on getting up in the morning in winter?

2. Do you get attacks of cough and phlegm lasting for at least three weeks each winter and for more than two winters?

3. Do you have to walk more slowly than men of your own age on the level because of breathlessness?

The prevalence of men with no symptoms, simple syndrome, and complex syndrome in relation to age, dust exposure, and presence or absence of pneumoconiosis is shown in Table IV. Because of the widely varying numbers in each sub-group, comparisons of statistical significance are obviously hazardous.

The striking feature of Table IV is that only $21 \%$ of the pure alumina workers complained of symptoms whereas the prevalence among men exposed to other dusts as well was $52 \%$ among those without pneumoconiosis and $69 \%$ among those with pneumoconiosis.

Men of the younger age group, who had worked with alumina only, had a low prevalence of the 'simple syndrome', but in the older men (over 45 years) there were no marked differences with regard to that syndrome between the three groups. On the other hand, more than $50 \%$ of the older men with pneumoconiosis complained of the 'complex syndrome' compared with $25 \%$ in the two other groups. A further analysis of the 32 men with radiological evidence of pneumoconiosis did not reveal any definite association between the prevalence of the two syndromes and 'rising' radiographic category (Table V).

\section{TABLE V}

Respiratory Symptoms of 32 China Biscuit Placers With RADIOGRAPHIC EvIDENCE OF PNEUMOCONIOSIS, ACCORDING TO Radiological Category (I.L.O., I959)

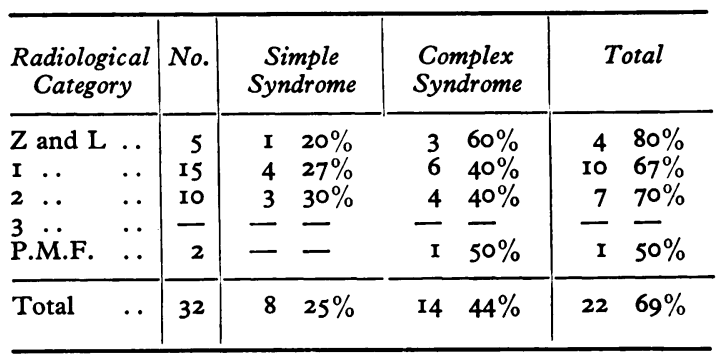

Smoking Habits Table VI shows the smoking habits of the 169 men according to age, dust exposure, and presence or absence of pneumoconiosis. Only eight of the 80 men below the age of 45 years had never or only occasionally smoked cigarettes, and only six of the 89 men older than 45 years were non-smokers in the accepted sense. There are no marked differences in the smoking habits in the three sub-groups at each age level. Only four men were 'ex-smokers' and seven mixed or pipe smokers.

In general, these findings are in accordance with the findings of Cross, McDowell, and Posner (1958), who noted that more male pottery workers in North Staffordshire were cigarette smokers than miners and other industrial workers in the area, and that the daily consumption of tobacco by potters was higher than by the other two groups. In fact, the china biscuit placers are slightly heavier smokers than a representative sample of all male pottery workers investigated in 1958 . 
TABLE VI

Smoking Habits of i69 China Placers and Oddmen, according to Age and Exposure to Dusts

\begin{tabular}{|c|c|c|c|c|c|c|c|c|c|c|c|c|c|c|c|c|c|c|}
\hline \multirow{3}{*}{$\begin{array}{c}\text { Age } \\
\text { (yrs.) }\end{array}$} & \multirow{2}{*}{\multicolumn{6}{|c|}{ Alumina Only }} & \multicolumn{12}{|c|}{ Other Dusts } \\
\hline & & & & & & & \multicolumn{6}{|c|}{ No Pneumoconiosis } & \multicolumn{6}{|c|}{ Pneumoconiosis Present } \\
\hline & No. & N.S. & Cig. & $\begin{array}{c}\text { Cig. } \\
I I\end{array}$ & $\mid \begin{array}{c}E x- \\
S m o k- \\
\text { ers }\end{array}$ & $\begin{array}{c}\text { Pipe } \\
\text { and } \\
\text { Mixed }\end{array}$ & No. & N.S. & Cig. & $\begin{array}{c}\text { Cig. } \\
I I\end{array}$ & $\mid \begin{array}{c}E x- \\
\text { Smok- } \\
\text { ers }\end{array}$ & $\begin{array}{c}\text { Pipe } \\
\text { and } \\
\text { Mixed }\end{array}$ & No. & $N . S$ & $\begin{array}{c}\text { Cig. } \\
I\end{array}$ & $\begin{array}{c}\text { Cig. } \\
I I\end{array}$ & $\mid \begin{array}{c}E x- \\
\text { Smok- } \\
\text { ers }\end{array}$ & $\begin{array}{c}\text { Pipe } \\
\text { and } \\
\text { Mixed }\end{array}$ \\
\hline $18-44$ & 50 & 5 & $\begin{array}{l}22 \\
44 \%\end{array}$ & $\begin{array}{l}21 \\
42 \%\end{array}$ & - & $\begin{array}{l}2 \\
4 \%\end{array}$ & 25 & $\begin{array}{l}3 \\
12 \%\end{array}$ & $\begin{array}{l}14 \\
56 \%\end{array}$ & $\begin{array}{c}8 \\
32 \%\end{array}$ & - & - & 5 & - & $\begin{array}{c}2 \\
40 \%\end{array}$ & $60 \%$ & - & - \\
\hline $45+$ & 8 & $\begin{array}{c}\text { I } \\
\text { I2.5\% }\end{array}$ & - & $\begin{array}{c}6 \\
75 \%\end{array}$ & - & I & 54 & $\begin{array}{l}4 \\
7 \%\end{array}$ & $\begin{array}{l}17 \\
32 \%\end{array}$ & $\begin{array}{l}28 \\
52 \%\end{array}$ & $\begin{array}{l}3 \\
5 \%\end{array}$ & $\begin{array}{l}2 \\
4 \%\end{array}$ & 27 & $\begin{array}{l}\text { I } \\
4 \%\end{array}$ & $\begin{array}{l}12 \\
44 \%\end{array}$ & $\begin{array}{l}11 \\
41 \%\end{array}$ & $\begin{array}{l}\text { I } \\
4 \%\end{array}$ & $\begin{array}{l}2 \\
7 \%\end{array}$ \\
\hline
\end{tabular}

N.S. Non-smokers who have never smoked more than an occasional cigarette.

Cig. I Up to I 9 cigarettes per day

Cig. II 20 cigarettes or more per day.

Pipe and mixed smokers These men smoked predominantly pipe tobacco plus occasional cigarettes.

The absence of marked differences in smoking habits between the three sub-groups allowed us to combine all non-smokers and cigarette smokers in Table VII, which shows the relation of smoking habits to respiratory syndromes in the two age groups. The high overall proportion of the complex syndrome in men older than 45 years emphasizes the importance of the age factor and, by implication, the length of time a man had been smoking. On the other hand, we found no significant differences in the prevalence of the complex syndrome in relation to the number of cigarettes smoked. The small number of 14 non-smokers does not allow any valid comparisons with the cigarette smokers.

\section{TABLE VII}

SMoking Habits aNd Respiratory Symptoms of 158 China Placers and OdDMEN : NoN-SMOKers AND Cigarette SMOKers

\begin{tabular}{|c|c|c|c|c|c|c|}
\hline Age (yrs.) & $\begin{array}{c}\text { Smoking } \\
\text { Habit }\end{array}$ & No. & \multicolumn{2}{|c|}{$\begin{array}{c}\text { Simple } \\
\text { Syndrome }\end{array}$} & \multicolumn{2}{|c|}{$\begin{array}{l}\text { Complex } \\
\text { Syndrome }\end{array}$} \\
\hline I 8-44 & $\begin{array}{l}\text { Non-smokers } \\
\text { Cig. I } \\
\text { Cig. II }\end{array}$ & $\begin{array}{r}8 \\
38 \\
32\end{array}$ & $\begin{array}{r}- \\
12\end{array}$ & $\begin{array}{l}-\overline{13 \%} \\
38 \%\end{array}$ & - & $\frac{-}{3 \%}$ \\
\hline $45+$ & $\begin{array}{l}\text { Non-smokers } \\
\text { Cig. I } \\
\text { Cig. II }\end{array}$ & $\begin{array}{r}6 \\
29 \\
45\end{array}$ & $\begin{array}{r}3 \\
12 \\
12\end{array}$ & $\begin{array}{l}50 \% \\
41 \% \\
27 \%\end{array}$ & $\begin{array}{r}2 \\
12 \\
16\end{array}$ & $\begin{array}{l}33 \% \\
41 \% \\
36 \%\end{array}$ \\
\hline
\end{tabular}

Non-smokers Never smoked more than an occasional cigarette

Cig. I Up to 19 cigarettes per day

Cig. II 20 cigarettes or more per day
Respiratory Function Tests The four consistent expiratory spirograms were measured to give the vital capacity (V.C.) and the indirect maximum breathing capacity (I.M.B.C.).' The latter was derived from the forced expiratory volume in 0.75 second (F.E.V. 0.75) as described by Kennedy (1953). Both the V.C. and the I.M.B.C. were obtained from the mean of the four consistent spirograms. In Figs. I and 2 they were expressed as a percentage of the predicted normal values according to the age and height of each man. We used the nomogram given by Cotes (1965) which is based on the data of Kory, Callahan, Boren, and Syner (196r).

From Figures $I$ and 2 it became clear that in many men the I.M.B.C. is impaired more than the V.C. and consequently we confined further analysis to the I.M.B.C. findings, which are generally considered to be a more useful index of pulmonary dysfunction than the V.C. (Gilson and Hugh-Jones, I949; McKerrow, 1960).

Absolute I.M.B.C. Values by Age and Dust Exposure These are shown in Table VIII. The obvious trend is the fall of the mean I.M.B.C. with age which applies to all three groups. Because of the widely varying numbers of men examined in each sub-group, and the very small number in some of them, comparisons at each age level are obviously difficult. In view of this the slightly higher values for men below the age of 45 who had been exposed to other dusts in addition to alumina (group II), compared with those who had worked with alumina only (group I), seem to be of little significance. In group III (men with pneumoconiosis), the mean I.M.B.C. was generally lower than in the two other 


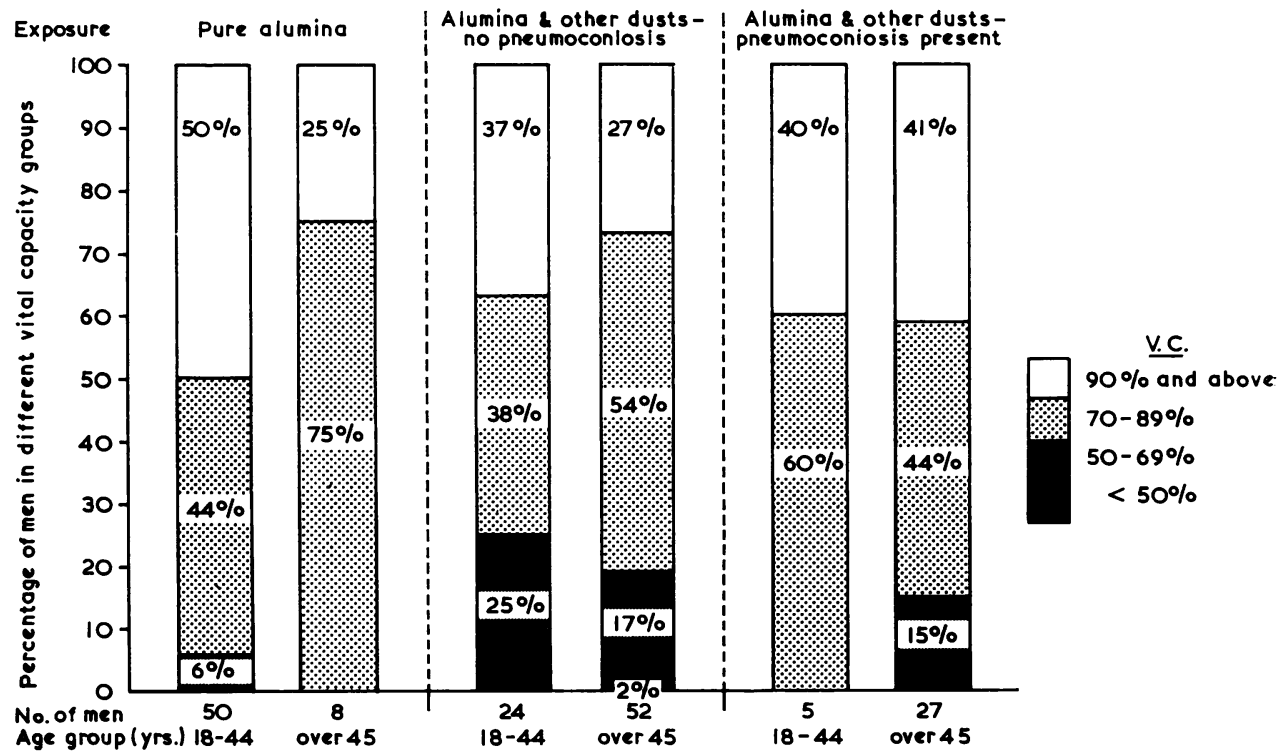

FIG. I. The individual vital capacities of the 166 china placers and oddmen were expressed as a percentage of the predicted normal, based on the age and height of the individual.

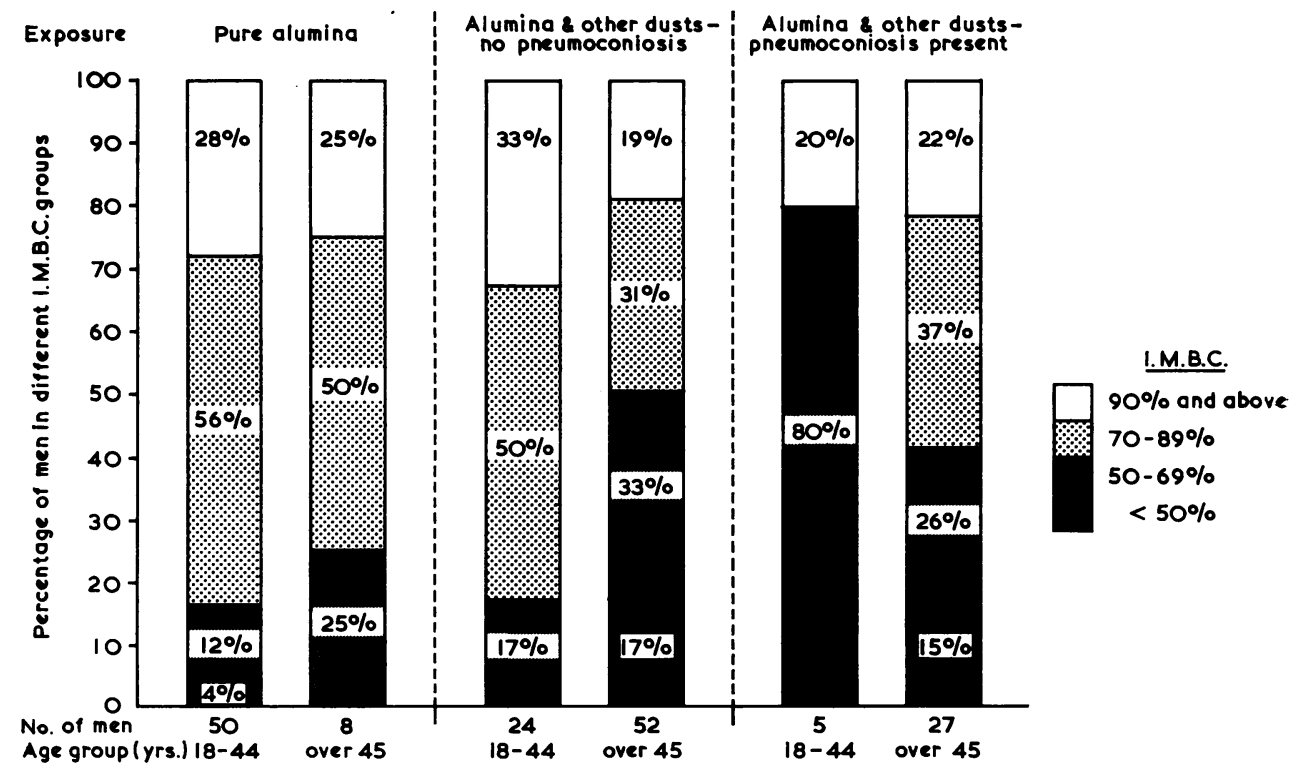

FIG. 2. The individual I.M.B.C.s of the I66 china placers and oddmen were expressed as a percentage of the predicted normal, based on the age and height of the individual. 
TABLE VIII

Mean I.M.B.C. of i66 China Biscuit Placers, according to Age, Height, and Exposure to Dust

\begin{tabular}{|c|c|c|c|c|c|c|c|c|c|c|c|c|c|}
\hline \multirow{3}{*}{$\begin{array}{l}\text { Age } \\
\text { Group } \\
\text { (yrs.) }\end{array}$} & \multirow{3}{*}{$\begin{array}{c}\text { No. } \\
\text { in } \\
\text { Group }\end{array}$} & \multirow{2}{*}{\multicolumn{4}{|c|}{ Alumina Only }} & \multicolumn{8}{|c|}{ Alumina and Other Dusts } \\
\hline & & & & & & \multicolumn{4}{|c|}{ No Pneumoconiosis } & \multicolumn{4}{|c|}{ Pneumoconiosis Present } \\
\hline & & No. & $\begin{array}{c}\text { Mean } \\
\text { Age } \\
\text { (yrs.) }\end{array}$ & $\begin{array}{c}\text { Mean } \\
\text { Height } \\
\text { (in.) }\end{array}$ & $\begin{array}{c}\text { Mean } \\
\text { I.M.B.C. } \\
\text { (l./min.) }\end{array}$ & No. & $\begin{array}{c}\text { Mean } \\
\text { Age } \\
\text { (yrs.) }\end{array}$ & $\begin{array}{c}\text { Mean } \\
\text { Height } \\
\text { (in.) }\end{array}$ & $\begin{array}{c}\text { Mean } \\
\text { I.M.B.C. } \\
\text { (l. } / \text { min. })\end{array}$ & No. & $\begin{array}{c}\text { Mean } \\
\text { Age } \\
\text { (yrs.) }\end{array}$ & $\begin{array}{c}\text { Mean } \\
\text { Height } \\
\text { (in.) }\end{array}$ & $\begin{array}{c}\text { Mean } \\
\text { I.M.B.C. } \\
\text { (l./min.) }\end{array}$ \\
\hline 25 & 20 & 15 & $\begin{array}{c}19 \\
(17-24)\end{array}$ & $\begin{array}{c}68 \\
(64-72)\end{array}$ & $\begin{array}{c}143 \\
(120-179)\end{array}$ & 5 & $\begin{array}{c}2 I \\
(19-23)\end{array}$ & $\begin{array}{c}69 \\
(68-70)\end{array}$ & $\begin{array}{c}158 \\
(140-170)\end{array}$ & - & - & - & - \\
\hline $25-34$ & 16 & II & $\begin{array}{c}31 \\
(25-34)\end{array}$ & $\begin{array}{c}66 \\
(63-71)\end{array}$ & $\begin{array}{c}133 \\
\left(\begin{array}{l}1 \\
1\end{array} 8-154\right)\end{array}$ & 5 & $\begin{array}{c}32 \\
(29-34)\end{array}$ & $\begin{array}{c}67 \\
(66-7 I)\end{array}$ & $\begin{array}{c}145 \\
(129-165)\end{array}$ & - & - & - & - \\
\hline $35-44$ & 43 & 24 & $\begin{array}{c}39 \\
(35-44)\end{array}$ & $\begin{array}{c}67 \\
(63-73)\end{array}$ & $\begin{array}{c}117 \\
(64-163)\end{array}$ & 14 & $\begin{array}{c}39 \\
(36-43)\end{array}$ & $\begin{array}{c}68 \\
(64-73)\end{array}$ & $\begin{array}{c}132 \\
(85-164)\end{array}$ & 5 & $\begin{array}{c}42 \\
(40-44)\end{array}$ & $\begin{array}{c}68 \\
(65-70)\end{array}$ & $\begin{array}{c}93 \\
(76-144)\end{array}$ \\
\hline $45-54$ & 44 & 5 & $\begin{array}{c}47 \\
(45-48)\end{array}$ & $\begin{array}{c}69 \\
(65-72)\end{array}$ & $\begin{array}{c}108 \\
(79-126)\end{array}$ & 28 & $\begin{array}{c}49 \\
(45-54)\end{array}$ & $\begin{array}{c}67 \\
(62-71)\end{array}$ & $\begin{array}{c}100 \\
(55-148)\end{array}$ & II & $\begin{array}{c}5 \mathrm{I} \\
(47-54)\end{array}$ & $\begin{array}{c}67 \\
(62-71)\end{array}$ & $\begin{array}{c}90 \\
(38-120)\end{array}$ \\
\hline $55+$ & 43 & 3 & $\begin{array}{c}56 \\
(58-62) \\
\end{array}$ & $\begin{array}{c}70 \\
(68-72)\end{array}$ & $\begin{array}{c}95 \\
(93-105)\end{array}$ & 24 & $\begin{array}{c}59 \\
(55-65)\end{array}$ & $\begin{array}{c}67 \\
(6 I-72)\end{array}$ & $\begin{array}{c}73 \\
(16-106)\end{array}$ & I6 & $\begin{array}{c}62 \\
(59-73)\end{array}$ & $\begin{array}{c}65 \\
(6 I-69)\end{array}$ & $\begin{array}{c}79 \\
(33-109)\end{array}$ \\
\hline Total & 166 & 58 & - & - & - & 76 & - & - & 一 & 32 & - & - & - \\
\hline
\end{tabular}

Figures in brackets indicate the range of measurements.

groups, except for the men above the age of 55, whose values are practically on the same level with those in the corresponding age group who had exposure to other dusts but no evidence of pneumoconiosis.

The rate of decline by age and exposure to dusts is shown in Figure 3. From the age of 35 years onwards it was steeper in men who had been exposed to other dusts in addition to alumina.

\section{I.M.B.C. Expressed as Percentage of Predicted}

Normal Figure 2 shows the proportions of men with I.M.B.C. values less than $70 \%$ of the predicted normal according to age and dust exposure. The first two columns represent men who had only been exposed to alumina. The third column refers to 24 men below the age of 45 years who had exposure to other dusts in addition to alumina, but no radiological evidence of pneumoconiosis. The proportion of men in these three columns who showed an I.M.B.C. of less than $70 \%$ of the predicted normal was approximately $20 \%$ (exact values in each
FIG. 3. The individual I.M.B.C. of the 166 china placers and oddmen were expressed as a percentage of the predicted normal, based on the age and height of the individual.

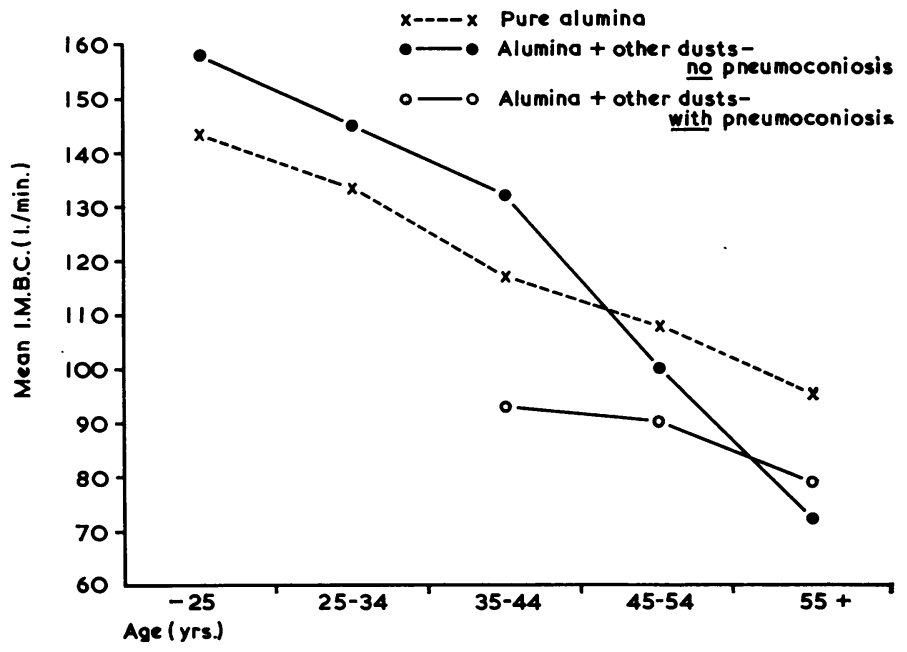


column being $16 \%, 25 \%$, and $17 \%$ ). Only four of the men in the third column had been exposed to flint dusts (one, two, four, and five years respectively) and one of them had also one year's exposure to earthenware dust. The remainder were either exminers with exposures ranging from one to 12 years (I4 men) or men who had worked in other pottery departments between one and Io years (six men).

The proportions of men with an I.M.B.C. of less than $70 \%$ of the predicted normal in columns IV, $\mathrm{V}$ and VI were considerably higher $(50 \%, 80 \%$, and $4 \mathrm{I} \%$ respectively) than columns I, II and III. Column IV relates to men over 45 years of age with no pneumoconiosis but who had been exposed to alumina and other dusts. Columns V and VI relate to men with pneumoconiosis exposed to alumina and other dusts. Four of the five men less than 45 years of age (column V) had been exposed to flint for four to six years and the fifth man had been a coal miner for 15 years.

Figure 2 suggests, therefore, that the proportion of men with an I.M.B.C. of less than $70 \%$ of the predicted normal value was higher in workmen who had been exposed to other industrial dusts in addition to alumina. These findings must be seen in the light of the absolute values in Table VIII and the limitations applicable to comparisons with normal values predicted from other sources. However, it seems safe to conclude that alumina does not cause as much respiratory impairment as some other dusts occurring in the pottery and coalmining industries.

Men with I.M.B.C. Values of less than $50 \%$ of Predicted Normal Those men with an I.M.B.C. less than $50 \%$ of the predicted normal value are listed in Table IX. All these men had been exposed to potentially hazardous dusts as well as to alumina with the exception of two workers who had worked with alumina only. These two men were only moderate smokers, had no respiratory symptoms, and had normal radiographs. The reason for the great reduction in their I.M.B.C. is not clear.

Of the remainder, four men had radiological changes suggestive of emphysema, and it is interesting that their I.M.B.C. values are among the lowest recorded. Two men had radiological evidence of bronchiectasis and their I.M.B.C. was only $30 \%$ and $35 \%$ of the predicted normal. There were six cases with no radiological abnormalities, two with simple pneumoconiosis only, and one case with healed tuberculosis.

In view of the surprising inconsistencies in some cases between the low I.M.B.C. values, clinical histories, and radiographic findings, this group of

TABLE IX

ANalysis of Age, Occupational Exposure, Smoking Habits, Respiratory Syndrome, and Radiological Appearances of i5 Men with I.M.B.C. BELOW 50\% OF EXPECTEd VALUE

\begin{tabular}{|c|c|c|c|c|c|c|c|c|c|}
\hline \multirow{2}{*}{ No. } & \multirow{2}{*}{ Age } & \multicolumn{4}{|c|}{ Exposure to Industrial Dusts (years) } & \multirow{2}{*}{$\begin{array}{l}\text { Smoking } \\
\text { Habits }\end{array}$} & \multirow{2}{*}{$\begin{array}{l}\text { Respiratory } \\
\text { Syndrome }\end{array}$} & \multirow{2}{*}{$\begin{array}{l}\text { Radiological } \\
\text { Appearance }\end{array}$} & \multirow{2}{*}{$\begin{array}{l}\text { I.M.B.C. } \\
\text { Percentage }\end{array}$} \\
\hline & & Alumina & Flint & Coal & Others & & & & \\
\hline I & 64 & 19 & $2 I$ & 6 & - & Cig. I & Complex & $\begin{array}{l}\text { Pneumoconiosis }(\mathrm{mI}) \text { and } \\
\text { Bronchiectasis }\end{array}$ & 35 \\
\hline 2 & 59 & 17 & 12 & - & - & Cig. I & Nil & Pneumoconiosis (mI) & 49 \\
\hline 3 & 54 & 5 & - & 12 & - & Cig. I & Nil & $\begin{array}{l}\text { Pneumoconiosis (m2) and } \\
\text { emphysema }\end{array}$ & 28 \\
\hline 4 & 47 & 14 & - & 15 & - & Cig. II & Complex & Pneumoconiosis (m2) & 48 \\
\hline 5 & 65 & 17 & 18 & 8 & - & Cig. II & Complex & Emphysema & 18 \\
\hline 6 & 56 & 24 & I I & - & - & Cig. I & & Emphysema & 38 \\
\hline 7 & 59 & 25 & 14 & - & 一 & $\begin{array}{l}\text { Ex-smoker } \\
\text { (Cig II }\end{array}$ & Complex & Emphysema & 12 \\
\hline 8 & 64 & 24 & $2 \mathrm{I}$ & 2 & - & Cig. II & Complex & Bronchiectasis & 30 \\
\hline 9 & 58 & 24 & 8 & - & - & Cig. II & Complex & Inactive tuberculosis & 46 \\
\hline Io & 39 & 2 & - & - & - & Cig. I & Nil & Normal & 48 \\
\hline II & $4 \mathrm{I}$ & 22 & - & - & - & Cig. I & Nil & Normal & 35 \\
\hline 12 & 55 & 16 & - & 25 & - & Cig. I & Complex & Normal & 47 \\
\hline 13 & 55 & 17 & - & - & Earthenware biscuit & Cig. II & Simple & Normal & 42 \\
\hline 14 & 48 & 6 & - & 25 & 24 & Cig. II & Simple & Normal & 45 \\
\hline 15 & 64 & 14 & - & 12 & 一 & Cig. II & Simple & Normal & 40 \\
\hline
\end{tabular}

Cig. I up to 19 cigarettes per day; Cig. II 20 cigarettes or more per day.

Note: Cases $I$ to 4 are also shown under the corresponding numbers in Table III. 


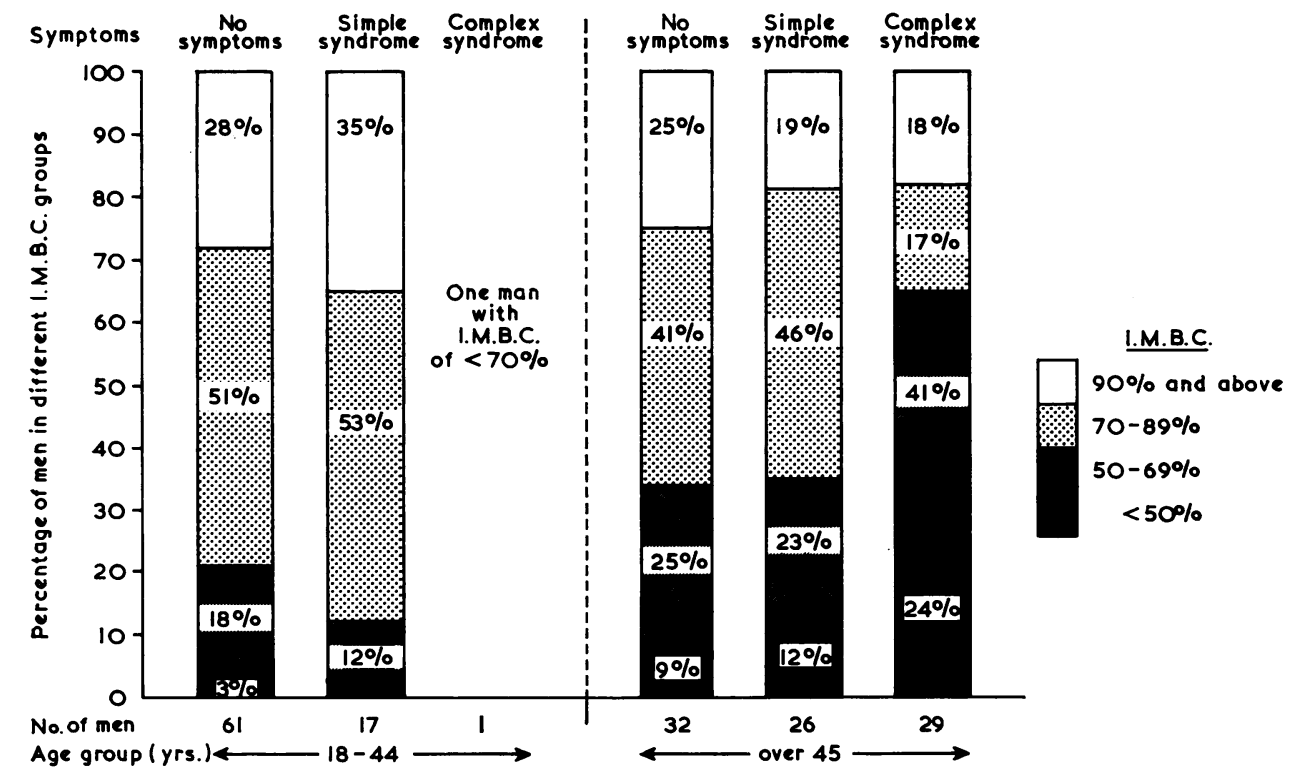

FIG. 4. The individual I.M.B.C.s of the 166 china placers and oddmen were expressed as a percentage of the predicted normal, based on the age and height of the individual.

I5 men will be further investigated as regards other parameters of lung function and will be reported later.

The relationship between respiratory symptoms and the I.M.B.C. is illustrated in Figure 4. There were 79 men aged 18 to 44 years and 87 men over 45 years of age.

Of the men aged 18 to 44 years, there were $6 \mathrm{I}$ with no symptoms, 17 with the simple syndrome, and only one with the complex syndrome. It can be seen from the histograms in Fig. 4 that there is no striking difference in the I.M.B.C. findings between those men with no symptoms and those men with the simple syndrome.

Of the men over 45 years of age, 32 had no symptoms, 26 had the simple syndrome, and 29 the complex syndrome. Again in this age group there was very little difference in the I.M.B.C. figures of those men with a simple syndrome and those men with no symptoms. However, the I.M.B.C. values of the men with the complex syndrome are, in general, considerably lower than those with no symptoms or the simple syndrome.

In all, there were 15 men with I.M.B.C. values less than $50 \%$ of the predicted normal, five of whom claimed to have no symptoms; three were classified as having the simple syndrome and seven as having the complex syndrome (Table IX).

\section{Discussion}

The most important result of the present investigation was the complete absence of radiologically manifest pneumoconiosis in workmen who had been exposed to alumina only. Furthermore we found no evidence that the I.M.B.C. of men who were 'pure alumina workers' was lower than that of those who had been exposed to other dusts as well (e.g., coal, flint, or composite ceramic dusts). In fact, in terms of 'percentage of predicted values' of I.M.B.C. the evidence points the other way.

The situation in the British pottery industry seems therefore to be quite different from that in other industries where serious chest disease has been reported as the result of inhalation of pure metallic aluminium (Goralewski, 1947, 1950; Mitchell, 1959; Mitchell, Manning, Molyneux, and Lane, 1961) or of mixed bauxite fumes (Shaver and Riddell, 1947; Shaver, 1948).

On the other hand, our results are in accordance with the experience of Kennedy (1956) who found no evidence of physiological or radiological changes as the result of prolonged inhalation of aluminium oxide dust in the course of therapeutic trials. In this context, a personal communication by the late Professor E. J. King, quoted in the report of the preceding survey (Meiklejohn and Posner, 1957), is of 
some interest. In this, King suggested that alumina as used in pottery manufacture is thoroughly dehydrated and its fibrogenicity thereby greatly reduced.

Nearly 30 years ago, in 1937, alumina was substituted for flint as a bedding medium in the pottery industry. The prediction by Plant (1939) that this event would prove to be an annus mirabilis for the industry seems to have withstood the test of time and follow-up studies.

We wish to thank the Pottery Manufacturers and workmen who co-operated in the survey, the staff of the Stoke-on-Trent Mass Radiography Service and of the Department of Respiratory Physiology of the City General Hospital in Stoke-on-Trent, for their excellent assistance. Dr. W. W. Jones very kindly acted as an adjudicator of the chest radiographs. E. Posner received a research grant from the Birmingham Regional Hospital Board.

\section{REFERENCES}

College of General Practitioners. (I96I). Brit. med.f., 2, 973. Cotes, J. E. (1965). Lung Function. Blackwell, Oxford.
Cross, K. W., McDowell, L. A., and Posner, E. (1958). Brit. med. $\mathcal{F} ., 1,862$.

Ferris, B. G., and Anderson, D. O. (1962). Amer. Rev. resp. Dis., 86, 165.

Fletcher, C. M., Elmes, P. C., Fairbairn, A. S., and Wood, C. H. (1959). Brit. med. f., 2, 257.

Gilson, J. C., and Hugh-Jones, P. (1949). Clin. Sci., 7, 185. Goralewski, G. (1947). Z. ges. inn. Med., 2, 665.

(1950). Die Aluminiumlunge. (Arbeitsmedizin, heft 26). Barth, Leipzig.

Higgins, I. T. T., Cochrane, A. L., Gilson, J. C., and Wood, C. H. (1959). Brit. F. industr. Med., 16, 255.

International Labour Office. (1959). Occup. Safety Hlth, 9, 63. Kennedy, M. C. S. (1953). Thorax, 8, 73.

(1956). Brit. F. industr. Med., 13, 85.

King, E. J., Harrison, C. V., Mohanty, G. P., and Nagelschmidt, G. (1955). F. Path. Bact., 69, 81.

Kory, R. C., Callahan, R., Boren, H. G., and Syner, J. C. (I96I). Amer. F. Med., 30, 243.

McKerrow, C. B. (1960). In Industrial Pulmonary Diseases: A Symposium. (Ed. King, E. J., and Fletcher, C. M.), p. 129. Churchill, London.

Meiklejohn, A. (1963). Brit. F. industr. Med., 20, 255. and Posner, E. (1957). Ibid., 14, 229.

Mitchell, J. (1959). Ibid., 16, 123.

-, Manning, C. B., Molyneux, M., and Lane, R. E. (I96I). Ibid., 18, 10.

Plant, H. J. (1939). Trans. Brit. Ceramic Soc., 38, 476.

Shaver, C. G. (1948). Occup. Med., 5, 7 I 8.

and Riddell, A. R. (1947). F. industr. Hyg., 29, 145. 